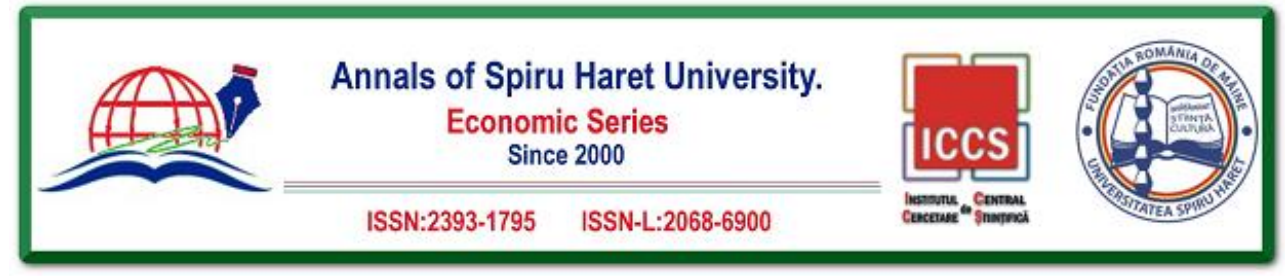

Issue 3/2018

\title{
STUDY ON THE INVOLVEMENT OF THE UNIVERSITY IN TRAINING AND LIFELONG LEARNING OF THE HIGH SCHOOL'S GRADUATES
}

\author{
Iuliana PÂRVU ${ }^{1}$, Iulia GRECU ${ }^{2}$, Paula-Cornelia MITRAN ${ }^{3}$, \\ Gheorghe GRECU ${ }^{4}$ \\ 1, 2, 3, 4 Spiru Haret University, Faculty of Law and Economics, 32-34 \\ Unirii Street, Constanta, Romania, Tel.: +40241545015, \\ Email: iuliana.parvu@spiruharet.ro,iulia.grecu@spiruharet.ro, \\ paula.mitran@spiruharet.ro,gheorghe.grecu@spiruharet.ro
}

How to cite: PÂRVU, I., GRECU, I., MITRAN, P.-C., GRECU, Gh. (2018). "Study on the Involvement of the University in Training and Lifelong Learning of the High School's Graduates." Annals of Spiru Haret University. Economic Series, 18(3), 97-106, doi: https://doi.org/10.26458/1837

\begin{abstract}
The nowadays continuously expansion of the market for higher education services puts a high pressure on the management of such institutions. Universities are trying to keep their position on the market by applying theories and practices that have traditionally been used by the business environment. This paper proposes to adapt such a practice to higher education institutions. This is the strategy of backward vertical integration. We understand this by highlighting the possibilities that higher education institutions have to take over some of the activities carried out in high schools. Starting from the experience of a project to whose implementation the authors participated, the paper describes how the counselling and vocational guidance activities addressed to high school students can be carried out by the higher education institutions.
\end{abstract}

Keywords: higher education market; backward vertical integration; counselling and vocational guidance.

JEL Classification: $\mathrm{I}_{23}$ 


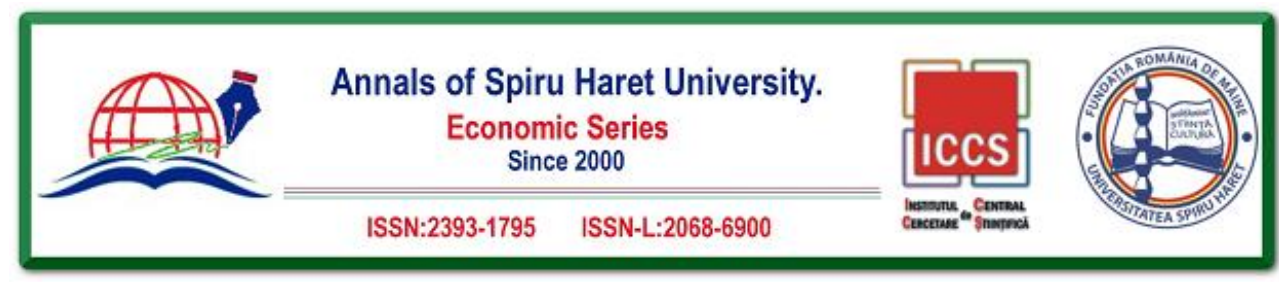

Issue 3/2018

\section{Introduction}

The higher education services market is a dynamic and growing one, characterized by intense competition. Global Higher Education Market 2016-2020 Study predicts a trend of market extension as a consequence of the "continuous advancements and rapid integration of new technologies, increased participation from developing nations, and the advent of new higher education institutes". As a result of the intense competition, universities must develop an organizational behaviour similar to that of the business environment. Thus, notions such as managerial strategies, marketing strategies, competitive advantage, promotional policies etc. are terms and concepts often used in the language and practice of the management of the higher education institutions. Of course, the specificity of the educational services cannot be overlooked, as business theory and practice cannot simply be translated into the field of university education services. As a consequence, it is important for the educational services market to build its own theoretical foundation in terms of managerial approaches.

To these observations we add those that highlight the need for high quality human resources in a knowledge-based society such as the present and the future one and the fact that "Universities represent the source of energy of the generation based on knowledge" (according to Janez Potočnik - European official) - in other words, the quality of human resources depends crushingly on the higher education system.

The present paper starts from two evidences, namely:

- The higher education services market is highly competitive and university management adopts business-specific theories and practices, but with some caution, since they must be adapted to the characteristics of higher education;

-The human resources needed by the present and the future socio-economic context are educated, able to use diverse and complex concepts, rough work being the task of the computerized equipment and technologies. So the universities are the institutions responsible for supporting professional and even personal development of the human resources.

Starting from the two observations, we propose and analyze the possibility of adapting, by the managerial teams of the universities, a well-known management strategy, namely upstream vertical integration.

\section{Literature Review}

Vertical integration as defined in the literature refers to expanding the coverage of the business' activity into the industry it belongs to. The concept is not new in 


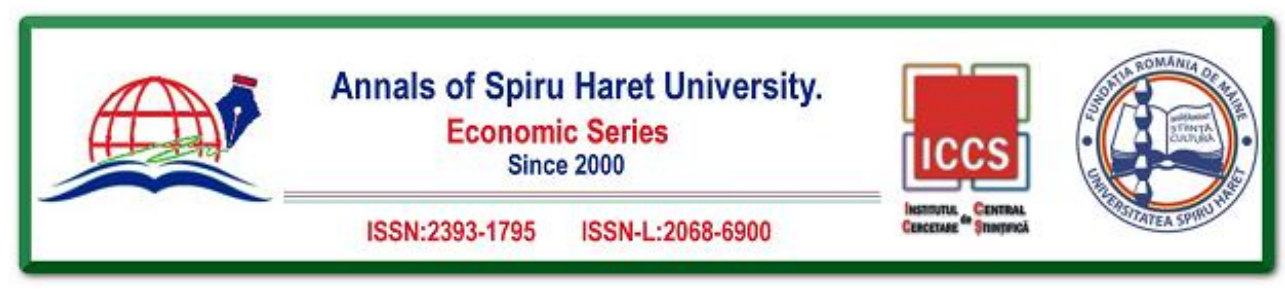

Issue 3/2018

literature and practice. It has long been a key force in the development of high productivity and managerial sophistication in U.S. business [Chandler, 1977]. A firm can be described as vertically integrated if it encompasses two single output production process in which the entire output of the upstream process is employed as part or all of the quantity of one intermediate input into the downstream process; or the entire quantity of one intermediate input into the downstream process is obtained from part or all of the output of the upstream process [Perry, 1989]

The conceptual development of this strategy has emerged "as a response to inefficiencies that arise when there is market power in both the upstream and downstream markets" [Joskow, 2010]. By appealing to such a strategy, companies seek to achieve "complete control over neighbouring stages of production and distribution and thus enjoys complete flexibility to make investment, production and distribution decisions" [Gambero, 2016].

In turn, vertical integration is treated as backward vertical integration or forward vertical integration. A company exhibits backward vertical integration when it controls subsidiaries that produce some of the inputs used in the production of its products. A company tends toward forward vertical integration when it controls distribution centres and retailers where its products are sold.

Vertical integration has been commonly used in industry, such as in automotive or oil companies, but current approaches to vertical integration highlight the fact that integration understand as $100 \%$ owned operations is outmoded. Modern firms take over just some stages of their operational process, either backward or upward.

By translating the issue of vertical integration into higher education, management theory and practice could raise the question of how universities can take over some of the upward activities, respectively those offered by the high schools. The approach is relatively new, which is why the literature does not analyze, theoretically substantiated, these aspects. However, literature discusses the fact that university and pre-university education are largely disconnected, which is why the problem of readiness of high school graduates for integration in a higher education institution is raised. [Davis, Ginns \& McRobbie, 2002].

In conclusion, we assert that the authors of this paper understand vertical integration (and, above all, upward integration) in higher education as studying the possibility for higher education institutions to get into the market of secondary school level activities. 


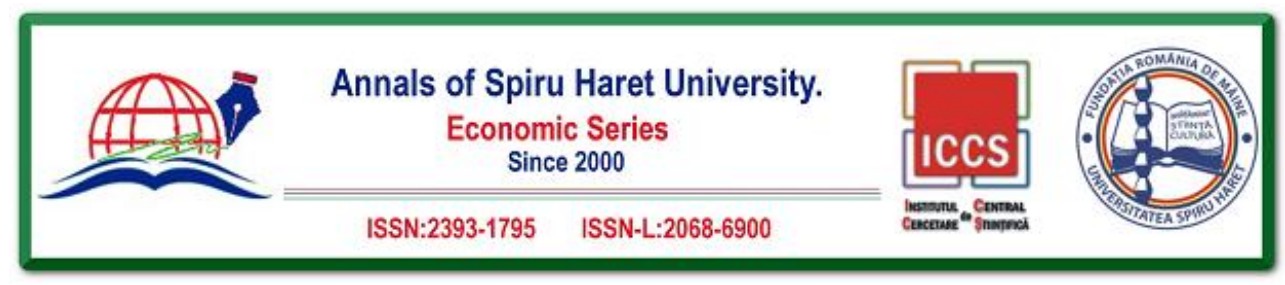

Issue 3/2018

\section{High Graduates in Romania}

Romania is constantly on the last positions among the EU countries in the international evaluations of the quality of education. Indicators such as the average length of education, the participation of young people in education and vocational training, the rate of NEET are some chapters in which Romania is in the last place in the European rankings. Relevant in this context is the fact that the share of young people aged between 18 and 24, who have completed at most eight grades and who do not attend any form of education or training, declined in 2016 from the 2006 level in most EU Member States, with the exception of Romania, the Czech Republic and Slovakia, according to Eurostat. Also, most EU Member States have improved their rate of early school leaving, with Romania making an exception in the context of this rate rising from $15.3 \%$ in 2008 to $19.1 \%$ in 2015 , respectively $18.5 \%$ in 2016 (the third highest rate in Europe). The national target set for 2020 is only $11.3 \%$ and the European average in 2016 was $10.7 \%$ (17\% in 2002).

Referring strictly to high school education, statistics (up to 2014-2015 for which data are available) highlight the following:

-Rate of early school leaving reached 3.7\%, up from previous years;

-The lowest rate of early school leaving is in the vocational branch $-1.6 \%$;

-The highest rate of early school leaving is in the technological branch $-5.4 \%$;

-In the theoretical branch, rate of early school leaving was $1.8 \%$; within this branch, the real profile is the one with the highest rate of school leaving $-2.2 \%$.

From the perspective of indicators aiming to capture the results of high school education, we observe a fluctuating evolution:

- The high school graduation rate (with and without a baccalaureate exam) is high and rising, respectively $89.1 \%$ for the $2014-2015$ promotion;

-Between 2004 and 2009, the rate of promoting the baccalaureate exam reached values of $60 \%-70 \%-75 \%$ (with the lowest value in 2006 , when it was $59.2 \%$ );

-Between 2010 and 2014, the rate of promoting the baccalaureate exam is $20 \%-30 \%-40 \%$ (with the lowest value in 2011 when it was $21.58 \%$ );

- In 2015 , the rate of graduation increased to $66.41 \%$ and in 2016 to $66.7 \%$.

Regarding the continuation of the studies by participating in the tertiary education of the high school graduates, the number of students enrolled in the first cycle of undergraduate studies decreased, reaching about 535,000 in 2015-2016, compared to approximately $1,100,000$ in $2009-2010$. 


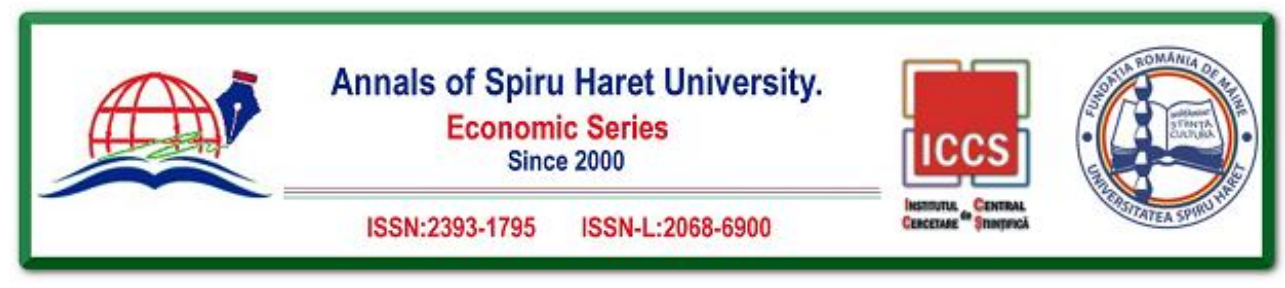

Issue 3/2018

Examples of Best Practice Regarding University-High School Institutions Collaboration

A field in which collaboration between universities and high schools can be successful is Career Counselling and Guidance. Taking over the attributions included in this area of responsibility can benefit both parties. Thus, high school institutions can benefit from an operational simplification of their work processes, while universities gain the benefit of better knowledge of the potential students, as well as the opportunity to direct future high school graduates to university.

Such a form of collaboration was made by Spiru Haret University, through the Faculty of Law and Economics, within the project We are building together your future professional career! implemented in partnership with "Niculae Titulescu" Technical College of Medgidia. The aim of the project was to increase the chances of success of the future high school graduates in the transition from school to higher levels of education or to work by providing an integrated program of career counselling and internship. From the perspective of the development of the collaboration in the field of Career Counselling and Guidance, the project had the following objectives:

- Increasing professionalism in organizing and carrying out counselling and professional guidance activities;

- Increasing student motivation in lifelong learning;

- Promoting the importance of acquiring "extra-professional" skills (the ability to solve new problems and to understand the context in which to act, the ability to adapt to any working conditions, acquiring relevant "emotional skills" at work, acquiring social skills etc.) in order to be successful in the professional and in the personal life.

As a result of the collaboration, within the faculty, the premises were created to ensure the sustainability of such a partnership, as follows:

$>$ An organizational structure within the higher education institution having as main task the coordination of the counselling activities - this department periodically reviews the objectives of the counselling program, the set of competencies and expected outcomes to be obtained by the pupils and makes recommendations on updating and refining the way the counselling program works. It is recommended that representatives from all stakeholders to be included in the counselling programs (pupils, parents, teachers in both upper and secondary education, counsellors, representatives of school management). Though the representation of all stakeholders is important, the size of the department should also be considered, as too many 


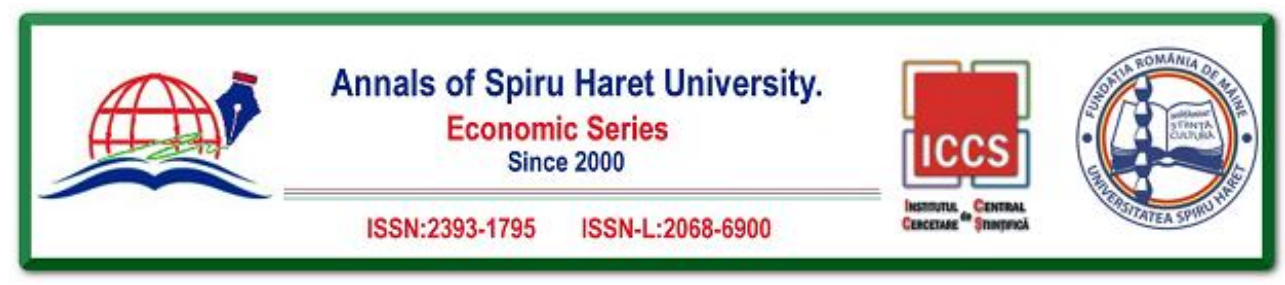

Issue 3/2018

members can lead to inefficiency. It is estimated that the number of members must range from 8 to 20 members.

> A data collection system necessary to: demonstrate the extent to which the objectives of the program are met; monitor student progress; to substantiate decisions on the counselling program etc. The data needed for the counselling programs come from a variety of sources and can be classified according to several criteria:

a. Data highlighting pupils' performance: average of grades; grades obtained on various subjects; graduation rate; diplomas obtained at school competitions; teachers' appraisals; parents' interest in pupils' school performance; participation in extracurricular activities etc.

b. Data highlighting the results of the counselling activity: the number of students who have developed career plans; the number of pupils who participated in internships; the number of students who have achieved their continuing education objectives; the number of students who resolved the conflicts they faced etc.

c. Data highlighting the factors that could determine pupils' performance differences: gender; ethnicity; socio-economic status; the spoken language at home; family status etc.

d. Program evaluation data: Number of parents attending meetings with counsellors; number of students participating in the counselling activities; number of career plans drawn up; the results of questionnaires through which parents, students, teachers appreciate counselling activity; evolution of the graduation rate; the evolution of absenteeism etc.

Most of the data presented above is, as a rule, easy to obtain using the information technology and databases currently used in the educational institution's activity. However, it is recommended that centralizing and compiling statistics to be not the task of the school counsellors.

To ensure the relevance of data that measure the impact of counselling activities, it is important that data to be analyzed and compared dynamically.

Even if data collection is a time consuming process, it should be noted that benefits exceed the costs involved.

Actions plans - in order to run an effective Career Counselling and Guidance Program, detailed plans are needed to describe how counsellors will work to achieve the results. Within action plans, for each theme it should be specified:

-Domain: academic, career, personal development, global perspective;

-The competences it develops;

-Description of how the counselling activity will be carried out; 


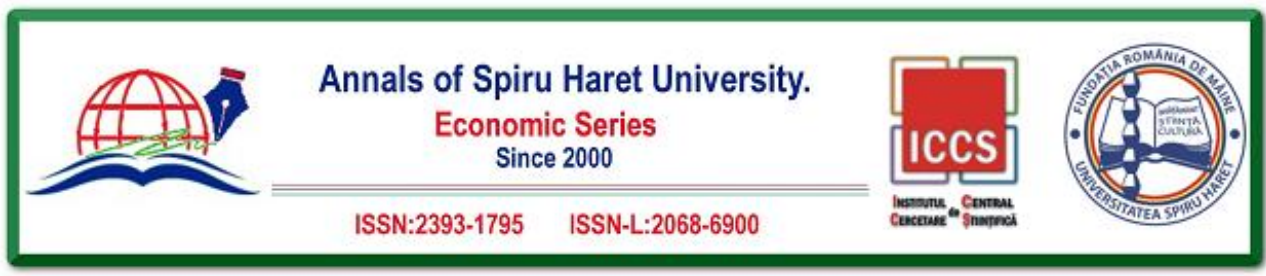

Issue 3/2018

-Highlighting the way in which the counselling activity will address each student;

- Time allocated to the theme;

-The name of the counsellor / counsellors responsible for carrying out activities specific to the theme;

-How students' success will be assessed, using various forms of testing and ways to demonstrate skills;

-Expected results from students expressed in the skills they can demonstrate;

-Plan approval by the management of the counselling program.

$>$ Time allocation refers to the time allocated to the counselling activities for each of the four components (program theme, activities specific to pupils' individual development, activities for pupils in special situations, organization of the counselling and vocational guidance system). While some experts assert that the time allocated does not matter, as long as the expected results are obtained, others argue that good results can only be achieved under the conditions of a rational allocation of time. In the book Developing and Managing Your School Guidance Program (4th ed.) it is recommended the following distribution of time between the components of the counselling programs in high schools:

Time distribution model between components of counselling programs

\begin{tabular}{||l||c||}
\hline \multicolumn{1}{|c||}{ Components of the counselling program } & Time allocation \\
\hline \hline Develop the program theme & $15-25 \%$ \\
\hline \hline Specific activities for the students' individual development & $25-35 \%$ \\
\hline \hline Activities for students in special situations & $25-35 \%$ \\
\hline \hline Organization of the counselling system & $15-20 \%$ \\
\hline
\end{tabular}

Source: Gysbers, Norman, "Individual Student Planning in the United States: Rationale, Practices and Results", in Asian Journal of Counselling, Vol. 15, No. 2, 2008, 117-139

It is very important to have a judicious allocation of time between counselling activities and non-counselling activities. Obviously, it is recommended that most of the counsellors' time be allocated to student meetings. 


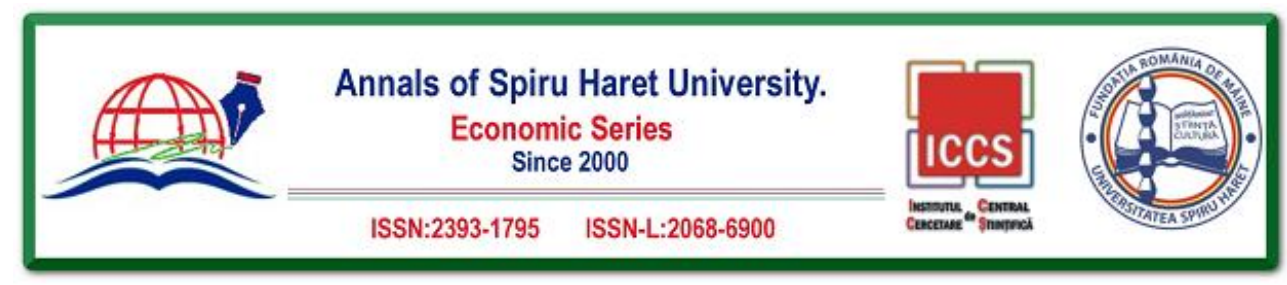

Issue 3/2018

Table 1. Activities that should and should not be carried out by the school counsellors

\begin{tabular}{|c|c|}
\hline $\begin{array}{l}\text { Recommended activities to be carried out } \\
\text { by the school counsellors }\end{array}$ & $\begin{array}{l}\text { Activities that are not recommended to } \\
\text { be run by the school counsellors }\end{array}$ \\
\hline $\begin{array}{l}\begin{array}{l}\text { Planning the educational route for each } \\
\text { student }\end{array} \\
\end{array}$ & $\begin{array}{l}\text { Scheduling students to the counselling } \\
\text { activities }\end{array}$ \\
\hline Analysis of the test results & Managing the test application process \\
\hline $\begin{array}{l}\text { Counselling students who are often late or } \\
\text { who have many absences }\end{array}$ & $\begin{array}{l}\begin{array}{l}\text { Responsibility } \\
\text { absences }\end{array} \\
\end{array}$ \\
\hline $\begin{array}{l}\text { Counselling and monitoring students with } \\
\text { disciplinary problems }\end{array}$ & $\begin{array}{l}\text { Appling corrective measures to students } \\
\text { with disciplinary problems }\end{array}$ \\
\hline Analyzing the evolution of the grades average & Calculation of the grades average \\
\hline Advising teachers for better coursework & Supervise classes \\
\hline $\begin{array}{l}\text { Assisting the management of the educational } \\
\text { institution to identify and solve the problems } \\
\text { of students in special situations }\end{array}$ & $\begin{array}{l}\text { Running administrative tasks specific to } \\
\text { school management }\end{array}$ \\
\hline
\end{tabular}

Source: Fezler, Brooke, Brown, Cheryl, International Model for School Counselling Programs. Association of American Schools in South America, 2011

The evidence of temporary planning of the counselling activities is represented by calendars. By publishing them, students, parents, teachers, school leaders are informed about the periods of the counselling activities and the place where they will be carried out. Calendars can be produced on an annual, monthly and weekly basis.

- Annual calendars - highlight priorities of the counselling activities. They must be displayed in places with visibility and in the spaces where the counselling activities take place. They must also be displayed on the high school website and sent as a newsletter to students and parents. The role of such calendars is multiple: promoting counselling activities, highlighting the most important events and activities for students and parents, improving communication between the educational institution and the students' families, organizing a structure in which counselling activities take place, strengthening the importance of student participation in counselling activities etc.

- Monthly calendars - highlight the most important events and activities that take place in the current month, including holidays. The indication is that 4 to 6 meetings with students to be scheduled monthly. 


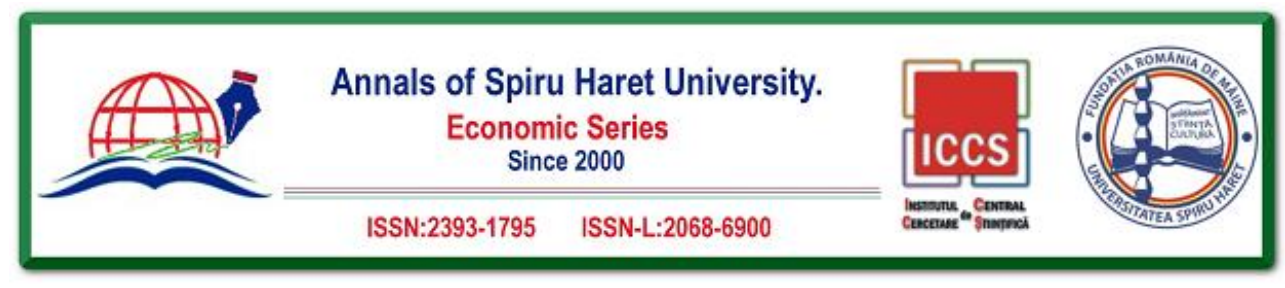

Issue 3/2018

- Weekly calendars - these are not mandatory, but only when unexpected changes occur due to students' needs.

\section{Conclusions}

The present paper is a proposal addressed to the management of the higher education institutions in perspective of the necessity to develop their services in order to succeed in the competitive struggle. Thus, a solution identified by the authors is backward vertical integration that universities can do through collaboration with high school institutions in order to take over part of the activities the latter are currently running.

Starting from the experience of a project funded by European funds that aimed precisely at such collaboration, the present paper presents a set of best practices in the field of collaboration for the taking over by the universities of the professional counselling and guidance activities. These good practices relate specifically to how a department can be organized within a higher education institution to ensure the smooth running of this collaboration.

The theme of this paper is one with a high degree of novelty that offers the opportunity of both a continuation from a theoretical perspective and a continuation from the perspective of identifying new types of activities traditionally conducted in high schools and which could be integrated into the activity of the universities.

\section{References}

1. Chandler, Alfred. The visible hand: The managerial resolution in American business. Cambridge, Mass.: Harvard University Press, 1977.

2. Davis, R. S., Ginns, I., McRobbie, C. (2002). 'Elementary school students' understanding of technology concepts." Journal of Technology Education, vol. 14, No. 1, 35-50.

3. Fezler, B., Brown, C. International Model for School Counselling Programs. Association of American Schools in South America, 2011.

4. Gambero, M. "Vertical Integration in Media Industries", Paper presented 16th Biennale Conference ITS Europe 4-6 September 2016 - Porto.

5. Gogu, E., Mureșan, M., Turdean, M. (2015). “Analiza statistică a evoluției absolvenților de liceu în România, în perioada 2010-2014." Revista pentru Asigurarea Calității în Învățământul Superior, vol. 6, nr. 1, 35-44.

6. Gysbers, N. (2008). "Individual Student Planning in the United States: Rationale, Practices and Results." Asian Journal of Counselling, Vol. 15, No. 2, 117-139. 


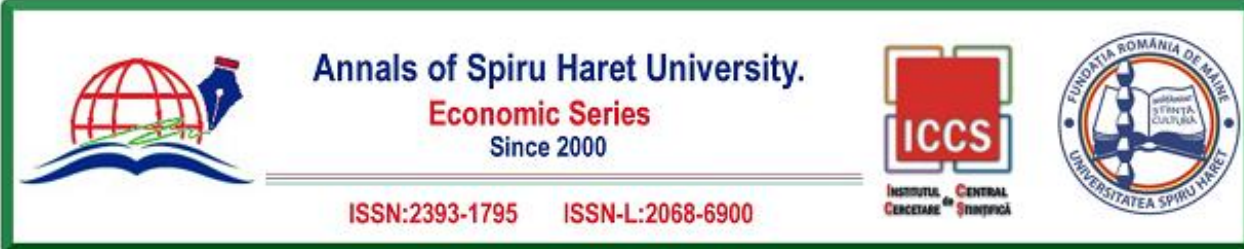

\section{Issue $3 / 2018$}

7. Pârvu, I., Mitran, P.-C. Ghid de bune practici în organizarea activităţilor de consiliere în cadrul instituţiilor de invățământ preuniversitar. Editura Leda, Constanţa, 2015.

8. Perry, M. K. "Vertical integration: Determinants and effects." In: R. Schmalensee \& R. Willig (eds.). Handbook of Industrial Organization, edition 1, volume 1, chapter 4, $183-255$.

9. *** Raport privind starea învățământului superior din România, 2016.

10. *** Raport privind starea învățământului preuniversitar din România, 2016. 


\section{DOCTORAL AND POSTDOCTORAL PAPERS}


